Article

\title{
Burnout Prevalence and Its Associated Factors among Malaysian Healthcare Workers during COVID-19 Pandemic: An Embedded Mixed-Method Study
}

\author{
Nurhanis Syazni Roslan 1,*(D), Muhamad Saiful Bahri Yusoff ${ }^{1}$, Ab Razak Asrenee ${ }^{2}$ and Karen Morgan ${ }^{3,4}$ \\ 1 Department of Medical Education, School of Medical Sciences, Universiti Sains Malaysia, \\ Kelantan 16150, Malaysia; msaiful_bahri@usm.my \\ 2 Department of Psychiatry, School of Medical Sciences, Universiti Sains Malaysia and Hospital USM, \\ Universiti Sains Malaysia, Kelantan 16150, Malaysia; asrenee@usm.my \\ 3 Perdana University-Royal College of Surgeons in Ireland School of Medicine, Kuala Lumpur 50490, Malaysia; \\ karenmorgan@perdanauniversity.edu.my \\ 4 Department of Health Psychology, Royal College of Surgeons in Ireland, D02 YN77 Dublin, Ireland \\ * Correspondence: nurhanis_syazni@usm.my; Tel.: +609-767-6554
}

check for updates

Citation: Roslan, N.S.; Yusoff, M.S.B.; Asrenee, A.R.; Morgan, K. Burnout

Prevalence and Its Associated Factors among Malaysian Healthcare

Workers during COVID-19

Pandemic: An Embedded

Mixed-Method Study. Healthcare 2021,

9, 90. http://doi.org/10.3390/

healthcare 9010090

Received: 17 December 2020

Accepted: 13 January 2021

Published: 17 January 2021

Publisher's Note: MDPI stays neutral with regard to jurisdictional clai$\mathrm{ms}$ in published maps and institutional affiliations.

Copyright: (C) 2021 by the authors. Licensee MDPI, Basel, Switzerland. This article is an open access article distributed under the terms and conditions of the Creative Commons Attribution (CC BY) license (https:// creativecommons.org/licenses/by/ $4.0 /)$.

\begin{abstract}
Coronavirus disease 2019 (COVID-19) has become a global health threat and has placed an extraordinary demand on healthcare workers around the world. In this study, we aim to examine the prevalence of burnout and its associated factors and experience among Malaysian healthcare workers during the COVID-19 pandemic through an embedded mixed-method study design. We found that more than half of Malaysian healthcare workers in this sample experienced burnout. Direct involvement in COVID-19 screening or treatment, having a medical condition, and less psychological support in the workplace emerged to be the significant factors in personal-, work-, and patient-related burnout. Participants described their workloads, uncertainties caused by the pandemic, challenging work-family balance, and stretched workplace relationships as the sources of burnout. Exhaustion appeared to be the major symptom, and many participants utilized problem-focused coping to deal with the adversities experienced during the pandemic. Participants reported physical-, occupational-, psychological-, and social-related negative impacts resulting from burnout. As the pandemic trajectory is yet unknown, these findings provide early insight and guidance for possible interventions.
\end{abstract}

Keywords: psychological well-being; burnout; health personnel; caregiver; pandemic; COVID-19

\section{Introduction}

In late December 2019, an increasing number of patients with pneumonia of an unknown etiology were seen in Wuhan, China. The causative virus was later identified as severe acute respiratory syndrome coronavirus 2 (SARS-CoV-2), and this novel pneumonia is called coronavirus disease 2019 (COVID-19) [1]. It immediately became a global public health threat due to its strong infectivity, even in the incubation period [2]. With the rapid increase of cases reported outside China, the World Health Organization (WHO) declared the COVID-19 outbreak a pandemic on 11 March 2020 [3]. As of 16 December 2020, 73.5 million people have been infected with COVID-19, with more than 1.6 million deaths reported worldwide.

The high transmissibility of the virus without the presence of vaccines can severely stretch healthcare workers (HCW) [4]. On top of facing a higher risk of infection from patient care [5] and a lack of personal protective equipment (PPE), HCW also fear transmitting the infection to their families and struggle with guilt over their patients and family members [6]. During the previous SARS outbreak in 2003, stress was observed in 57\% of a sample of HCW [7]. In the COVID-19 pandemic, studies have shown higher anxiety levels among Chinese HCW as compared to the general population [8-10]. About $42.5 \%$ of Thai HCW were identified to have at least mild anxiety symptoms [11]. Another study revealed 
that $64.7 \%, 51.6 \%$, and $41.2 \%$ of Turkish HCW displayed symptoms of depression, anxiety, and stress, respectively [12].

While several studies outlined the prevalence of depression, anxiety, and stress, less is known about HCW burnout. Burnout can be defined as a syndrome resulting from chronic workplace stress that has not been successfully managed [13]. Burnout is not synonymous with fatigue, stress, or depression [14] and is known to affects helping professions such as HCW. It is characterized by energy depletion or emotional exhaustion, negativity related to one's job, and reduced professional efficacy $[15,16]$. Previous research has linked burnout to various personal and patient care impacts, such as decreased professionalism, empathy, patient safety, teamwork and increased medical errors and attritions [17-19]. A high prevalence of burnout has been seen among HCW post-natural disasters [20,21]. We postulated that there is a similar occurrence in a pandemic setting. Burnout can result from an increased work demand and decreased job resources, along with value conflicts [22], and this link has been further magnified during COVID-19. Burnout can also emanate from disproportionately huge effort and low satisfaction, making the most dedicated HCW feel vulnerable, especially in pandemic times [16].

For the past two decades, burnout research has identified several risk factors at the individual and situational levels [23]. At the individual level, younger age has been consistently associated with a higher risk of developing burnout $[18,24]$. Some studies also found that single HCW were at a higher risk for burnout as compared to their married counterparts [24], while having children has been associated with a lower risk of developing burnout [25]. The role of spiritual well-being was also explored, as it influenced burnout development through emotional intelligence [26]. At the situational level, long hours have been found to be associated with burnout, with each additional hour worked per week increasing the risk of developing burnout by $2 \%$ [24,25]. In line with the Job DemandResource theory [27], poor health and inadequate psychological support in the workplace have been linked to burnout development [28,29], with mixed results [30]. These associations have yet to be explored in the context of a pandemic and may provide understanding that is important in designing effective burnout prevention measures for HCW.

In Malaysia, the healthcare system has increased its COVID-19 preparedness since 6 January 2020 when screening and surveillance measures were strengthened. The first case was detected on 24 January 2020, and the Restriction of Movement Order (RMO) was put into place on 18 March 2020 [17]. As of 16 December 2020, 86,618 cases have been detected, with 422 deaths reported, in the country. With the increasing trend of confirmed cases, HCW continue to serve the country in the various roles of surveillance, screening, diagnosis, and treatment. Thus, building from the above conceptual framework, we aim to examine burnout prevalence and its association with demographic characteristics among Malaysian HCW and explore their burnout experiences during the COVID-19 pandemic in an embedded mixed-method study. We hypothesized that burnout prevalence is high among HCW and factors such as direct involvement with COVID-19, long hours, being young or single, having a medical condition, having no children or having inadequate childcare support, inadequate psychological support in the workplace, and irregular spiritual routines were associated with a higher risk of developing burnout.

\section{Materials and Methods}

\subsection{Study Design}

As the phenomenon of burnout in the context of a pandemic is less understood, we adopted a mixed-method approach with an embedded design $[31,32]$. In order to estimate the prevalence of burnout among Malaysian HCW, we conducted a cross-sectional study using an online instrument. Through a descriptive phenomenological approach, we captured the HCW experience using open-ended questions to explore the main quantitative data from the cross-sectional study. 


\subsection{Participants}

Using snowball sampling, we invited Malaysian assistant medical officers, doctors, health inspectors, hospital food preparation personnel, medical laboratory technologists, nurses, paramedics, pharmacists, physicians, physiotherapists, dieticians, therapists, psychologists, counsellors, radiographers, and social workers from public and private healthcare services to enroll in this study. The required sample size for the study, with 9 predictors, an anticipated effect size of 0.02 , and $30 \%$ a nonresponse rate, was 1126 [33].

\subsection{Instrument}

The instrument package included sociodemographic questions, the Copenhagen Burnout Inventory (CBI), and open-ended questions. The demographic questions included the workplace setting, involvement with COVID-19 patients, working hours, age, marital status, number of children, availability of childcare at home, medical conditions, perceived psychological support at the workplace, and spirituality routines.

The CBI is an instrument to measure occupational burnout with excellent psychometric properties and is available in the public domain. It has three dimensions that include personal-related (6 items), work-related ( 7 items), and patient-related burnout ( 6 items). Each item was rated on a scale of always/to a very high degree (100), often/to a high degree (75), sometimes/somewhat (50), seldom/to a low degree (25), and never/to a very low degree (0) [34]. The CBI was also validated in a pandemic context, with a Cronbach's alpha coefficient of 0.94 [35]. For this study, we used the Malay translated CBI (CBI-M), which was validated and found to have a Cronbach's alpha coefficient of 0.83-0.87 [36]. We calculated the average scores for each dimension, where an average score of $50 \%$ or above is treated as burnout [37].

At the end of the instrument, all participants were invited to answer four optional self-declared open-ended questions. These questions were tested to ensure that they were able to capture the intended research questions. The final questions were as follows:

If you have experienced burnout, you are invited to share your experience below:

1. What caused burnout in yourself?

2. What were the burnout symptoms that you experienced?

3. How did you try to cope with the symptoms?

4. How did the symptoms affect your work or your life (if at all)?

\subsection{Data Collection}

In line with the RMO, we conducted the study using Google Forms between 21 April 2020 and 20 May 2020. During the beginning of the data collection, Malaysia was in its third month of facing COVID-19 under the second phase of RMO. We sent the invitation link through the Ministry of Health official website and HCW-related nongovernmental organizations Facebook pages. In the informed consent form, we emphasized to the participants the anonymity and confidentiality of the data. There were no monetary incentives given, but the participants received the option to gather information on their burnout scores and helplines that may be useful.

\subsection{Data Analysis}

We analyzed the quantitative component using SPSS version 24 (IBM Corp., Armonk, N.Y., USA). We applied descriptive statistics to examine the personal-, work-, and patient-related burnout prevalences. We performed simple logistic regression to assess the relationships between each independent variable (involvement with COVID-19, working hours, age, marital status, children, availability of childcare support in the pandemic, medical conditions, perceived psychological support at the workplace, and spirituality routine) with all the dimensions of burnout. With the same set of independent variables, we performed multiple logistic regression to find significant relationships between each of the independent variables and dimensions of burnout by controlling the other independent variables. We presented both crude and adjusted odds ratios, along with 95\% confidence 
intervals (CI) and $p$-values. In order to evaluate the nonresponse bias, we also compared the prevalences of the first $50 \%$ versus the last $50 \%$ participants who enrolled in the study.

In the qualitative analysis, we included the open-ended responses from the participants who scored more than $50 \%$ in their CBI. We analyzed the data using a thematic analysis on computer-assisted software, Atlas.Ti version 8.1 (Atlas.Ti GmbH, Berlin, Germany). NSR open-coded and organized the coding into themes. MSBY reviewed the coding and themes, and their agreement was generally concordant. In order to enhance the trustworthiness of the findings, we also used data sources triangulation and code-recode procedures (an intra-rater agreement method to enhance reliability where NSR recoded the data after some time to compare with the initial coding) during the data analysis process [38].

\section{Results}

\subsection{Participants Characteristics}

A total of $933 \mathrm{HCW}$ completed the online instruments, with a response rate of $82.9 \%$. We excluded 40 entries due to incomplete quantitative responses or duplicates. The demographic characteristics of the participants are summarized in Table 1. The highest participation was from doctors, social workers, and assistant medical officers. The majority of the participants worked in government hospitals, had indirect involvement with COVID-19 patients, worked $60 \mathrm{~h}$ or more weekly, were aged less than 40 years old, married, had children, had adequate childcare support at home, had no medical conditions, perceived that they received adequate psychological support at work, and practiced a regular spiritual routine.

Table 1. Demographic characteristics of the healthcare workers (HCW) enrolled in the study $(n=893)$.

\begin{tabular}{cc}
\hline Demographic Characteristics & $\boldsymbol{n} \mathbf{( \% )}$ \\
\hline Healthcare worker categories & \\
Doctor & $203(22.7)$ \\
Social worker & $128(14.3)$ \\
Assistant medical officer & $120(13.4)$ \\
Medical laboratory technologist & $99(11.1)$ \\
Hospital food preparation personnel & $88(9.9)$ \\
Physiotherapist/Dietician/Therapist & $69(7.7)$ \\
Nurse & $47(5.3)$ \\
Radiographer & $41(4.6)$ \\
Pharmacist & $40(4.5)$ \\
Paramedic & $25(2.8)$ \\
Health inspector/Public health assistant & $22(2.5)$ \\
Psychologist/Counsellor & $11(1.2)$ \\
Workplace setting & \\
Government hospitals & $607(68.0)$ \\
Health clinics & $134(15.0)$ \\
District health offices & $52(5.8)$ \\
Medical laboratories & $39(4.4)$ \\
Private hospitals & $35(3.9)$ \\
Private clinics & $26(2.9)$ \\
\hline Less than 60 h per week & \\
Direct (Treating/Screening) & $406(45.5)$ \\
Indirect & $487(54.5)$ \\
\hline Involvement with COVID 19 pandemic & $257(28.8)$ \\
\hline
\end{tabular}


Table 1. Cont.

\begin{tabular}{|c|c|}
\hline Demographic Characteristics & $n(\%)$ \\
\hline $60 \mathrm{~h}$ per week or more & $636(71.2)$ \\
\hline \multicolumn{2}{|l|}{ Age } \\
\hline Less than 40 years & $682(76.4)$ \\
\hline 40 years and above & $211(23.6)$ \\
\hline \multicolumn{2}{|l|}{ Marital status } \\
\hline Single & $274(30.7)$ \\
\hline Married & $619(69.3)$ \\
\hline \multicolumn{2}{|l|}{ No of children } \\
\hline No & $337(37.7)$ \\
\hline Yes & $556(62.3)$ \\
\hline \multicolumn{2}{|l|}{$\begin{array}{l}\text { Childcare support at home during COVID } 19 \\
\text { pandemic }\end{array}$} \\
\hline Had child at home with adequate support & $402(45.0)$ \\
\hline Had child at home with inadequate support & $152(17.0)$ \\
\hline \multicolumn{2}{|l|}{ Medical condition } \\
\hline No & $708(79.3)$ \\
\hline Yes & $185(20.7)$ \\
\hline \multicolumn{2}{|l|}{$\begin{array}{l}\text { Perceived psychosocial support at the } \\
\text { workplace }\end{array}$} \\
\hline Adequate & $622(69.7)$ \\
\hline Inadequate & $271(30.3)$ \\
\hline \multicolumn{2}{|l|}{ Spirituality routines } \\
\hline Regular & $757(84.8)$ \\
\hline Irregular & $136(15.2)$ \\
\hline
\end{tabular}

\subsection{Prevalence of HCW Burnout in the COVID-19 Setting}

The overall prevalence of personal-, work-, and patient-related burnout in this sample of Malaysian HCW was $53.8 \%, 39.1 \%$, and $17.4 \%$, respectively. There were no significant differences in any of these burnout prevalence levels between the first $50 \%$ and last $50 \%$ of the participants. Personal-related burnout was the highest among pharmacists and HCW in district health offices, work-related burnout was highest among health inspectors and HCW in medical laboratories, and patient-related burnout was highest among paramedics and HCW in private hospitals. Participants who were directly involved in screening or treating COVID-19 patients, aged less than 40 years, married, had no children, had inadequate childcare support at home, had a medical condition, perceived that they received inadequate psychosocial support at work, or had irregular spiritual routines were found to burnout more in all three dimensions of the CBI (Table 2). 
Table 2. Prevalence of burnout during the coronavirus disease 2019 (COVID-19) pandemic based on participants' characteristics $(n=893)$.

\begin{tabular}{|c|c|c|c|}
\hline Demographic Characteristics & $\begin{array}{c}\text { Personal- } \\
\text { Related Burnout } \\
n(\%)\end{array}$ & $\begin{array}{c}\text { Work- } \\
\text { Related Burnout } \\
n(\%)\end{array}$ & $\begin{array}{c}\text { Patient- } \\
\text { Related Burnout } \\
n(\%)\end{array}$ \\
\hline \multicolumn{4}{|l|}{ Healthcare worker categories } \\
\hline Overall & $480(53.8)$ & $349(39.1)$ & $155(17.4)$ \\
\hline Doctor & $129(63.5)$ & $104(51.2)$ & $54(26.6)$ \\
\hline Social worker & $44(34.4)$ & $22(17.2)$ & $10(7.8)$ \\
\hline Assistant medical officer & $74(61.7)$ & $51(42.5)$ & $32(26.7)$ \\
\hline Medical laboratory technologist & $65(65.7)$ & $53(53.5)$ & $15(15.2)$ \\
\hline Hospital food preparation personnel & $34(39.1)$ & $17(19.5)$ & $2(2.3)$ \\
\hline Physiotherapist/Dietician/Therapist & $27(39.1)$ & $18(26.1)$ & $8(11.6)$ \\
\hline Nurse & $26(55.3)$ & $21(44.7)$ & $7(14.9)$ \\
\hline Radiographer & $23(56.1)$ & $17(41.5)$ & $8(19.5)$ \\
\hline Pharmacist & $31(77.5)$ & $21(52.5)$ & $8(20.0)$ \\
\hline Paramedic & $10(40.0)$ & $9(36.0)$ & $7(28.0)$ \\
\hline Health inspector/Public health assistant & $14(63.6)$ & $14(63.6)$ & $3(13.6)$ \\
\hline Psychologist/Counsellor & $3(27.3)$ & $2(18.2)$ & $1(9.1)$ \\
\hline \multicolumn{4}{|l|}{ Workplace setting } \\
\hline Government hospitals & $318(52.4)$ & $230(37.9)$ & 105 (17.3) \\
\hline Health clinics & $73(54.5)$ & $49(36.6)$ & $25(18.7)$ \\
\hline District health offices & $33(63.5)$ & $26(50.0)$ & $9(17.3)$ \\
\hline Medical laboratories & $22(56.4)$ & $20(51.3)$ & $3(7.7)$ \\
\hline Private hospitals & $13(50.0)$ & $9(34.6)$ & $6(23.1)$ \\
\hline Private clinics & $21(60.0)$ & $15(42.9)$ & $7(20.0)$ \\
\hline \multicolumn{4}{|l|}{ Involvement with COVID 19 pandemic } \\
\hline Direct (Treating/Screening) & $255(62.8)$ & $197(48.5)$ & $100(24.6)$ \\
\hline Indirect & $225(46.2)$ & $152(31.2)$ & $55(11.3)$ \\
\hline \multicolumn{4}{|l|}{ Working hours in COVID 19 pandemic } \\
\hline Less than $60 \mathrm{~h}$ per week & $176(68.5)$ & $151(58.8)$ & $65(25.3)$ \\
\hline $60 \mathrm{~h}$ per week or more & $304(47.8)$ & $298(31.1)$ & $90(14.2)$ \\
\hline \multicolumn{4}{|l|}{ Age } \\
\hline Less than 40 years & $396(58.1)$ & $292(42.8)$ & $138(20.2)$ \\
\hline 40 years and above & $84(39.8)$ & $57(27.0)$ & $17(8.1)$ \\
\hline \multicolumn{4}{|l|}{ Marital status } \\
\hline Single & $160(58.4)$ & $127(46.4)$ & $61(22.3)$ \\
\hline Married & $320(51.7)$ & $222(35.9)$ & $94(15.2)$ \\
\hline \multicolumn{4}{|l|}{ No of children } \\
\hline No & $201(59.6)$ & $155(46.0)$ & $76(22.6)$ \\
\hline Yes & $279(50.2)$ & $194(34.9)$ & $79(14.2)$ \\
\hline \multicolumn{4}{|l|}{ Childcare support at home during } \\
\hline Had child at home (adequate support) & $172(42.8)$ & $109(27.1)$ & $42(10.4)$ \\
\hline Had child at home (inadequate support) & $107(70.4)$ & $85(55.9)$ & $37(24.3)$ \\
\hline \multicolumn{4}{|l|}{ Medical condition } \\
\hline No & $351(49.6)$ & $252(35.6)$ & $110(15.5)$ \\
\hline Yes & $129(69.7)$ & $97(52.4)$ & $45(24.3)$ \\
\hline \multicolumn{4}{|l|}{$\begin{array}{l}\text { Perceived psychosocial support at the } \\
\text { workplace }\end{array}$} \\
\hline Adequate & $256(41.2)$ & $158(25.4)$ & $64(10.3)$ \\
\hline Inadequate & $224(82.7)$ & $191(70.5)$ & $91(33.6)$ \\
\hline \multicolumn{4}{|l|}{ Spirituality routine } \\
\hline Regular & $394(52.0)$ & $276(36.5)$ & $122(16.1)$ \\
\hline Irregular & $86(63.2)$ & $73(53.7)$ & $33(24.3)$ \\
\hline
\end{tabular}




\subsection{Demographic Associations with Burnout}

Significant demographic associations with personal-, work-, and patient-related burnout are shown in Tables 3 and 4. At the univariate level, we found that inadequate self-perceived psychosocial support at work, long hours, direct involvement with COVID19, inadequate childcare support at home, medical conditions, younger age, being single, having no children, and irregular spirituality routines were significantly associated with all dimensions of burnout. At the multivariate level, younger age, direct involvement with COVID-19 patients, long hours, medical conditions, inadequate self-perceived psychological support at work, and inadequate childcare support were significantly associated with personal-related burnout. Direct involvement with COVID-19 patients, long hours, medical conditions, adequate self-perceived psychological support at work, inadequate childcare support, and irregular spirituality routines were significantly associated with work-related burnout. Younger age, direct involvement with COVID-19 patients, medical conditions, and inadequate self-perceived psychological support at work were significantly associated with patient-related burnout.

Table 3. Significant associations between the demographic characteristics and burnout using simple logistic regression $(n=893)$.

\begin{tabular}{|c|c|c|}
\hline Burnout Dimension and Demographic Characteristics & $\begin{array}{c}\text { Crude Odds Ratio } \\
*(95 \% \text { CI })\end{array}$ & $p$-Values \\
\hline $\begin{array}{c}\text { Personal-related burnout } \\
\text { Perceived psychosocial support received at work: } \\
\text { Inadequate }\end{array}$ & $6.81(4.79-9.70)$ & $<0.001$ \\
\hline Work more than $60 \mathrm{~h}$ per week & $2.37(1.75-3.22)$ & $<0.001$ \\
\hline Child support at home: Inadequate & $2.35(1.61-3.42)$ & $<0.001$ \\
\hline Suffering from some medical illness & $2.34(1.66-3.31)$ & $<0.001$ \\
\hline Age: Less than 40 years old & $2.09(1.53-2.87)$ & $<0.001$ \\
\hline Direct involvement with COVID-19 & $1.97(1.50-2.57)$ & $<0.001$ \\
\hline Spirituality routines: Irregular & $1.59(1.09-2.31)$ & 0.017 \\
\hline Children: None & $1.47(1.12-1.93)$ & 0.006 \\
\hline Relationship status: Single & $1.31(0.98-1.75)$ & 0.064 \\
\hline $\begin{array}{c}\text { Work-related burnout } \\
\text { Perceived psychosocial support received at work: } \\
\text { Inadequate }\end{array}$ & $7.01(5.11-9.63)$ & $<0.001$ \\
\hline Work more than $60 \mathrm{~h}$ per week & $3.15(2.34-4.25)$ & $<0.001$ \\
\hline Child support at home: Inadequate & $2.29(1.61-3.27)$ & $<0.001$ \\
\hline Direct involvement with COVID-19 & $2.08(1.58-2.73)$ & $<0.001$ \\
\hline Age: Less than 40 years old & $2.02(1.44-2.84)$ & $<0.001$ \\
\hline Spirituality routines: Irregular & $2.02(1.40-2.92)$ & $<0.001$ \\
\hline Suffering from some medical illness & $2.00(1.44-2.77)$ & $<0.001$ \\
\hline Children: None & $1.59(1.21-2.10)$ & 0.001 \\
\hline Relationship status: Single & $1.55(1.16-2.06)$ & 0.003 \\
\hline $\begin{array}{l}\text { Patient-related burnout } \\
\text { Perceived psychosocial support received at work: } \\
\text { Inadequate }\end{array}$ & $4.41(3.07-6.33)$ & $<0.001$ \\
\hline Age: Less than 40 years old & $2.90(1.70-4.92)$ & $<0.001$ \\
\hline Direct involvement with COVID-19 & $2.57(1.79-3.68)$ & $<0.001$ \\
\hline Work more than $60 \mathrm{~h}$ per week & $2.05(1.43-2.94)$ & $<0.001$ \\
\hline Children: None & $1.76(1.24-2.49)$ & 0.002 \\
\hline Suffering from some medical illness & $1.75(1.18-2.59)$ & 0.005 \\
\hline Child support at home: Inadequate & $1.70(1.12-2.58)$ & 0.013 \\
\hline Spirituality routines: Irregular & $1.67(1.08-2.58)$ & 0.022 \\
\hline Relationship status: Single & $1.60(1.12-2.29)$ & 0.010 \\
\hline
\end{tabular}


Table 4. Significant associations between the demographic characteristics and burnout using multiple logistic regression $(n=893)$.

\begin{tabular}{|c|c|c|c|}
\hline Burnout Dimension and Demographic Characteristics * & Nagelkerke $R^{2}$ & $\begin{array}{l}\text { Adjusted Odds Ratio } \\
(95 \% \mathrm{CI})\end{array}$ & $p$-Values \\
\hline Personal-related burnout & 0.288 & & \\
\hline $\begin{array}{l}\text { Perceived psychosocial support received at work: } \\
\text { Inadequate }\end{array}$ & & $5.50(3.80-7.97)$ & $<0.001$ \\
\hline Suffering from some medical illness & & $2.78(1.87-4.13)$ & $<0.001$ \\
\hline Child support at home: Inadequate & & $1.87(1.19-2.95)$ & 0.007 \\
\hline Work more than $60 \mathrm{~h}$ per week & & $1.82(1.29-2.58)$ & 0.001 \\
\hline Direct involvement with COVID-19 & & $1.60(1.17-2.18)$ & 0.003 \\
\hline Age: Less than 40 years old & & $1.55(1.05-2.27)$ & 0.027 \\
\hline Work-related burnout & 0.338 & & \\
\hline $\begin{array}{l}\text { Perceived psychosocial support received at work: } \\
\text { Inadequate }\end{array}$ & & $5.81(4.12-8.19)$ & $<0.001$ \\
\hline Work more than $60 \mathrm{~h}$ per week & & $2.65(1.87-3.75)$ & $<0.001$ \\
\hline Suffering from some medical illness & & $2.31(1.56-3.42)$ & $<0.001$ \\
\hline Spirituality routines: Irregular & & $1.94(1.26-2.99)$ & 0.003 \\
\hline Child support at home: Inadequate & & $1.92(1.22-3.02)$ & 0.005 \\
\hline Direct involvement with COVID-19 & & $1.68(1.22-2.32)$ & 0.002 \\
\hline Patient-related burnout & 0.200 & & \\
\hline $\begin{array}{l}\text { Perceived psychosocial support received at work: } \\
\text { Inadequate }\end{array}$ & & $3.49(2.38-5.13)$ & $<0.001$ \\
\hline Direct involvement with COVID-19 & & $2.21(1.50-3.26)$ & $<0.001$ \\
\hline Age: Less than 40 years old & & $1.86(1.03-3.39)$ & 0.041 \\
\hline Suffering from some medical illness & & $1.85(1.20-2.86)$ & 0.006 \\
\hline
\end{tabular}

* Only statistically significant ( $p$-values < 0.05) characteristics were shown in the table. * 95\% CI: $95 \%$ confidence interval.

\subsection{Qualitative Findings}

\subsubsection{Sources of Burnout}

In total, $72.7 \%$ of HCW with a high burnout score responded to the open-ended questions. Through a thematic analysis, we found that the most-described sources of burnout were their workload (long hours, working with extra precaution measures, team dynamic disruptions, the diffuse impact of pandemic, and bureaucracy matters). Some participants also described uncertainties caused by the pandemic (unpredictability of the course of the pandemic, frequent standard operating procedure (SOP) and role changes, quarantine, and disruption in their career plan); a challenged work-family balance (disruption of the work-family balance, confinement impact on the family, fear of transmitting COVID-19 to family, and financial loss); and stretched workplace relationships (superiors, colleagues, and patients) as contributors to their burnout (Table 5). 
Table 5. Common self-reported causes of burnout in HCW.

\begin{tabular}{cc}
\hline Theme & Qoding \\
& $\begin{array}{c}\text { "I am involved in setting up the quarantine and low risk treatment } \\
\text { centre, and I've been working until late. Once I reached home, I just } \\
\text { bed down. At this stage there are many unexpected things-those } \\
\text { big number of late night admissions, working late night... you just } \\
\text { need to prepare for all kind of possibilities." }\end{array}$
\end{tabular}

(P811, Dietician)

Working with extra precaution measures

Affecting the team dynamic that previously functioned well

Workload

Affecting every healthcare worker, including outside COVID-19 centers

Bureaucracy matters

Unpredictability of the pandemic course

Uncertainty from pandemic
Frequent change of roles

"The fatigue is constant. We need to stand for three to four hours in full PPE while handling samples."

(P119, Lab technologist)

"Some staffs were reallocated to screening and emergency team, some had to undergo quarantine and the loads just keep increasing."

(P49, Assistant medical officer)

"Even I am not in a COVID-19 treatment centre, our hospital receives more patients with other complaints. The load become unbearable with small number of manpower."

(P871, Medical intern)

"There are loads of paper works to be done especially towards the end of the month. I have to sleep less to get them over and done with."

(P740, Nurse)

"I'm scared that the pandemic will last until next year. The leave is frozen and I can't go back to my hometown. I just hope this feeling will not escalate to depression."

(P744, Pharmacist)

"I need to brainstorm on ways to regulate the staffs, especially front liners. The constant change of SOP does affect the service. It is also tiresome to keep briefing the staffs."

(P104, Assistant medical officer)

"I am currently reallocated in the medical department. It is uncertain how long will I be in this department. Someday, I have to work in the screening area, someday in COVID-19 ward and other places."

(P22, Medical resident)

"I feel anxious to handle Patient Under Investigation admissions in the quarantine centre. I have to deal both with my current role (in quarantine centre) and my original job scope that is sanitary water inspection and sampling. I feel this is physically and emotionally taxing."

(P813, Health inspector)

"I've become more burnout after becoming Patient Under

Quarantine Investigation myself. I was quarantined after being exposed to a COVID-19 patient in clinic."

(P2, General practitioner)

"My wedding and master's program registration needed to be postponed due to COVID-19."

(P746, Medical resident)

Own plan changes

Affecting the previous work-family dynamic

work-family balance
"My children are taken care by my elderly parents at home. They are all bored and the house is in wreck as they are $24 \mathrm{~h}$ at home. I wanted to help with the chores but I came back from work completely tired."

(P874, Medical resident)

“I feel so burnt-out as I couldn't visit my family who resides in other state."

(P99, Assistant medical officer) 
Table 5. Cont.

\begin{tabular}{|c|c|c|}
\hline Theme & Coding & Quotations \\
\hline & $\begin{array}{l}\text { Fear of passing the virus to family } \\
\text { members }\end{array}$ & $\begin{array}{l}\text { "I find this emotionally exhaustive, I feel so stressed as I fear to be } \\
\text { infected with this deadly virus. I feel that I have risk myself and my } \\
\text { family to treat other patients." } \\
\text { (P275, Assistant medical officer) }\end{array}$ \\
\hline & Financial loss & $\begin{array}{l}\text { "My husband salary were cut. I let out my anger to my three year } \\
\text { old toddler and the stress keeps building up." } \\
\text { (P229, Lab technologist) }\end{array}$ \\
\hline \multirow{3}{*}{$\begin{array}{l}\text { Stretched } \\
\text { workplace } \\
\text { relationships }\end{array}$} & Superiors & $\begin{array}{l}\text { "I needed to work on the same data entry six times just for a patient. } \\
\text { You could just extract the information from the system but our new } \\
\text { specialist insists to do it the old-fashioned way. I just think it's not } \\
\text { wise to do that when you are working in a hospital with full IT } \\
\text { access." } \\
\text { (P866, Medical resident) } \\
\text { "I got severe headaches and feeling frustrated as I was frequently } \\
\text { scolded from my superiors. The superiors were also tired and let } \\
\text { off the steam to us." } \\
\text { (P872, Medical intern) }\end{array}$ \\
\hline & Colleagues & $\begin{array}{l}\text { "I have to answer the WhatsApp on work-related even after } \\
\text { working hours. I am always pressured by the doctors. The other } \\
\text { technologists seem to not understand their role and gave the } \\
\text { burden to me." } \\
\text { (P801, Lab technologist) }\end{array}$ \\
\hline & Patients' attitudes & $\begin{array}{l}\text { "In this pandemic times, I got so tired when patients come to the } \\
\text { hospital without the right indication. Some patients came for trivial } \\
\text { complaints. And the interns ordered wrong films too." } \\
\text { (P421, Radiographer) } \\
\text { "Some patients did not declare that they had close contacts with } \\
\text { COVID-19 patients. And when I knew about it, I continuously feel } \\
\text { anxious. I feel scared that I could spread the virus. I hope there will } \\
\text { be a proper mechanism to fine patients who give wrong } \\
\text { information, so they will be more transparent." } \\
\text { (P480, Radiographer) }\end{array}$ \\
\hline
\end{tabular}

\subsubsection{Burnout Symptoms}

The most reported symptoms were overwhelming exhaustion (emotional, physical, and frustration). HCW also described symptoms of cynicism (distant attitude towards work and making callous comments to patients) and reduced professional accomplishment (loss of enthusiasm, a feeling of underperforming, and low self-esteem) (Table 6). 
Table 6. Common self-reported symptoms of burnout in HCW.

\begin{tabular}{|c|c|c|}
\hline Theme & Coding & Quotations \\
\hline \multirow{3}{*}{ Exhaustion } & Emotional exhaustion & $\begin{array}{l}\text { "It's more of emotional exhaustion rather than physical." } \\
\text { (P820, Pharmacist) } \\
\text { "Exhausted mentally, and sometimes this leads to physical exhaustion as well." } \\
\text { (P531, Medical intern) }\end{array}$ \\
\hline & Physical exhaustion & $\begin{array}{l}\text { "I'm just too tired even to think." (P617, Lab technologist) } \\
\text { "I feel like crawling to my car when work finishes. It feels like the hospital and } \\
\text { my house are so far away (than it is)." } \\
\text { (P231, Lab technologist) } \\
\text { "I sometimes don't drive home because I was just too tired and I slept in the on } \\
\text { call room instead." } \\
\text { (P167, Specialist doctor) } \\
\text { "Working for a day sometimes feels like a week because we are tired physically } \\
\text { and mentally. It might appear easy but donning PPE takes time and we wear } \\
\text { them for so long." } \\
\text { (P153, Lab technologist) }\end{array}$ \\
\hline & Frustration & $\begin{array}{l}\text { "Mentally exhausted, as we need to care for other person and their well-being, } \\
\text { while we have our own struggle at home with these home schooling (due to } \\
\text { COVID-19). Both of us are working, kids need to be sent to their grandparents, } \\
\text { homework keep coming through those WhatsApp group everyday leaving us } \\
\text { feeling even more hopeless. I cannot help but feel very guilty to the kids." } \\
\text { (P244, Specialist doctor) }\end{array}$ \\
\hline \multirow[t]{2}{*}{ Cynicism } & $\begin{array}{l}\text { Distant attitude towards } \\
\text { work }\end{array}$ & $\begin{array}{l}\text { "The first sign for me was fatigue, then feeling weary, I just go like, "Another } \\
\text { mass sampling!". Third, I become demotivated, numb and work just to finish } \\
\text { them (rather than wholeheartedly). Only God understand the fatigue." } \\
\text { (P894, Assistant medical officer) } \\
\text { "...I don't think this (working in COVID-19) is worth it." } \\
\text { (P277, Medical resident) } \\
\text { "I have to work from 8am to 5pm while other people can enjoy their } \\
\text { quarantine at home." } \\
\text { (P191, Lab technologist) } \\
\text { "I am easily angry over my job and there was once I nearly punch someone." } \\
\text { (P719, Health inspector) }\end{array}$ \\
\hline & $\begin{array}{l}\text { Callous comments about } \\
\text { patients or others }\end{array}$ & $\begin{array}{l}\text { "I am so resentful of those patients who seems disgusted by the front liners } \\
\text { wearing PPE." } \\
\text { (P333, Paramedic) } \\
\text { "I feel sick hearing COVID-19 word. Every patients use COVID-19 as excuses. } \\
\text { I just feel like telling people off when they say that word." } \\
\text { (P742, Pharmacist) }\end{array}$ \\
\hline \multirow{3}{*}{$\begin{array}{l}\text { Reduce personal } \\
\text { accomplishment }\end{array}$} & $\begin{array}{l}\text { Loss of enthusiasm or } \\
\text { work purpose }\end{array}$ & $\begin{array}{l}\text { "I've lost motivation to continue my usual work." } \\
\text { (P861, Allied health worker) } \\
\text { "I've no motivation to come to work almost every morning as the annual leave } \\
\text { is frozen. The patient load is huge and the workforce is barely adequate." } \\
\text { (P605, Pharmacist) }\end{array}$ \\
\hline & $\begin{array}{l}\text { Feeling of } \\
\text { underperforming }\end{array}$ & $\begin{array}{l}\text { "Exhausted and not productive at work." } \\
\text { (P540, Hospital food preparation personnel) } \\
\text { "I feel tired and sleepy after working only half day through. I have no energy } \\
\text { to work in the evening." } \\
\text { (P794, Pharmacist) } \\
\text { "I feel numb and lack of motivation at the morning. I don't feel prepared } \\
\text { mentally to start work since the job scope changes during COVID-19." } \\
\text { (P811, Social worker) }\end{array}$ \\
\hline & Low self-esteem & $\begin{array}{l}\text { "I just feel giving up on everything." } \\
\text { (P447, Lab technologist) } \\
\text { "I feel hopeless and useless for the past } 3 \text { weeks, life is just work." } \\
\text { (P18, Medical resident) }\end{array}$ \\
\hline
\end{tabular}




\subsubsection{Coping with Burnout}

The most described coping mechanisms among HCW were problem-focused coping (active and planning), followed by positive thinking coping (positive reinterpretation, acceptance, and humor). Participants also utilized support-seeking to cope, including emotional, instrumental, and spiritual support. The least-mentioned coping methods were maladaptive coping, which were self-distraction, behavioral disengagement, venting, and substance abuse (Table 7).

Table 7. Common self-reported coping strategies among burnt-out HCW.

\begin{tabular}{|c|c|c|}
\hline Theme & Coding & Quotations \\
\hline \multirow[t]{2}{*}{$\begin{array}{l}\text { Problem-focused } \\
\text { coping }\end{array}$} & Active coping & $\begin{array}{l}\text { "I arranged myself for counselling session and psychiatric assessment" } \\
\text { (P842, Specialist doctor) } \\
\text { "I take intermittent break and do some light exercises when I feel } \\
\text { exhausted or drenched in sweats from wearing PPE for hours to handle } \\
\text { diagnostic tests." } \\
\text { (P155, Lab technologist) } \\
\text { "Teamwork, sharing the load with your teammates, and getting the } \\
\text { support from the management keep me going. I stayed at the } \\
\text { accommodation centre provided by the ministry." } \\
\text { (P811, Dietician) }\end{array}$ \\
\hline & Planning & $\begin{array}{l}\text { "There's a lot on my mind every time I wake up. My body feels heavy. } \\
\text { Sometimes I had decision-paralysis. But I try to set up realistic aims and } \\
\text { 'just do it'." } \\
\text { (P854, Pharmacist) }\end{array}$ \\
\hline \multirow{3}{*}{$\begin{array}{l}\text { Positive thinking } \\
\text { coping }\end{array}$} & Positive reinterpretation & $\begin{array}{l}\text { "Just stay strong and remind myself that the public needs me" } \\
\text { (P85, Assistant medical officer) } \\
\text { "...just try to think positive. Sometimes when you got stressed up, I sing or } \\
\text { dance a bit, as long as I feel positive. I also ask for help when necessary. } \\
\text { My team is the best." } \\
\text { (P153, Lab technologist) }\end{array}$ \\
\hline & Acceptance & $\begin{array}{l}\text { "Accept the situation wholeheartedly, put my reliance to God and keep } \\
\text { moving forward." } \\
\text { (P894, Assistant medical officer) } \\
\text { "I just come to work and return home when work is done. I have to keep } \\
\text { going as this is what I do for a living." } \\
\text { (P118, Lab technologist) }\end{array}$ \\
\hline & Humor & $\begin{array}{l}\text { "I try to crack some jokes." } \\
\text { (P283, Social worker) }\end{array}$ \\
\hline \multirow{3}{*}{ Seeking social support } & Emotional support & $\begin{array}{l}\text { "I shared my feelings with } 90 \% \text { of my colleagues who are also burnt out." } \\
\text { (P866, Medical resident) } \\
\text { "I shared what happened during the day to my spouse." } \\
\text { (P197, Assistant medical officer) }\end{array}$ \\
\hline & Instrumental support & $\begin{array}{l}\text { "I talk about it to my colleagues, share some experience, because it is not } \\
\text { an individual problem so we help out each other." } \\
\text { (P153, Lab technologist) }\end{array}$ \\
\hline & Spirituality & $\begin{array}{l}\text { "I keep praying to Allah that this will be over soon." } \\
\text { (P71, Assistant medical officer) } \\
\text { "I recite the Quran to find some peace." } \\
\text { (P356, Social worker) }\end{array}$ \\
\hline Maladaptive coping & Self-distraction & $\begin{array}{l}\text { "I tried to find other source of happiness to forget about work stress. Those } \\
\text { stress will be gone for a while but I still be troubled about the workload } \\
\text { there and then." } \\
\text { (P519, Medical intern) }\end{array}$ \\
\hline
\end{tabular}


Table 7. Cont.

\begin{tabular}{ll}
\hline Theme Coding & \multicolumn{1}{c}{ Quotations } \\
\hline Venting & $\begin{array}{l}\text { "I JUST VENT MY ANGER AT HOME." } \\
\text { (P726, Medical resident) } \\
\text { "Sometimes I accidentally take it out on patients, but if I am too frustrated } \\
\text { or angry I just take it out on them. It might taint the image of healthcare } \\
\text { worker but some patients are rude too." } \\
\text { (P533, Medical resident) }\end{array}$ \\
& $\begin{array}{l}\text { "I just asked my housemen to do all (the duties)." } \\
\text { (P476, Medical resident) } \\
\text { "I kind of ignore the stress." } \\
\text { (P890, Assistant medical officer) }\end{array}$ \\
& $\begin{array}{l}\text { "I take alcohol after work (to ease the stress)." } \\
\text { (P848, Assistant medical officer) }\end{array}$ \\
\hline Substance abuse &
\end{tabular}

\subsubsection{Impact}

The impacts of burnout can be generally categorized as occupational, physical, psychological, and social (Table 8). The most-described impacts were physical (headaches, muscular pain, sleep disturbance, ailments, palpitations, appetite loss, and near accidents). Participants also reported occupational impacts, such as a lack of focus, loss of enthusiasm, and low productivity. The described psychological impacts included irritability, anger outbursts, and anxiety symptoms, while the social impacts included negatively affected family relationships and quality of life. Some participants observed no impacts from burnout in any of these categories.

Table 8. Common self-reported burnout impacts in HCW.

\begin{tabular}{|c|c|c|}
\hline Theme & Coding & Quotations \\
\hline \multirow{5}{*}{ Occupational } & Lack of focus & $\begin{array}{l}\text { "The burnout takes away my focus at work especially when dealing with fussy } \\
\text { patients." } \\
\text { (P589, Assistant medical officer) } \\
\text { "This burnout does affect my concentration and decision making ability." } \\
\text { (P400, Specialist doctor) } \\
\text { "I did not realize that I drive to a different health clinic because I was sleepy. I } \\
\text { was working long hours till late night and needed to response to WhatsApp } \\
\text { messages to make sure the supplies are adequate." } \\
\text { (P195, Pharmacist) }\end{array}$ \\
\hline & Loss of enthusiasm & $\begin{array}{l}\text { "I feel like not coming out from my car to work." } \\
\text { (P75, Allied health member) } \\
\text { "I feel less motivated to give my best to the patients." } \\
\text { (P241, Medical resident) } \\
\text { "I feel less prepared psychologically especially when starting the duties at the } \\
\text { morning. The MCO had many sports and recreational outlets closed, when I } \\
\text { need them to reduce the work stress." } \\
\text { (P811, Social worker) }\end{array}$ \\
\hline & Lack of productivity & $\begin{array}{l}\text { "Yes, I am not productive as I used to. I cannot continue my postgraduate } \\
\text { revision due to exhaustion." } \\
\text { (P634, Medical resident) } \\
\text { "Day by day I was not able to give the quality of work expected from me." } \\
\text { (P781, Assistant medical officer) }\end{array}$ \\
\hline & $\begin{array}{l}\text { Affecting the professional } \\
\text { relationship with patients }\end{array}$ & $\begin{array}{l}\text { "These burnout sometimes affect our communication with patients." } \\
\text { (P426, Paramedic) }\end{array}$ \\
\hline & Affecting professionalism & $\begin{array}{l}\text { "I tend to find excuses to be absent from work." } \\
\text { (P676, Medical resident) }\end{array}$ \\
\hline
\end{tabular}


Table 8. Cont.

\begin{tabular}{|c|c|c|}
\hline Theme & Coding & Quotations \\
\hline & Escape fantasies & $\begin{array}{l}\text { "There is not much in terms of personal life quality. I always sit down and } \\
\text { think how do I run away from all these." } \\
\text { (P210, Lab technologist) } \\
\text { "I feel like quitting and thinking about just staying at home." } \\
\text { (P361, Radiographer) }\end{array}$ \\
\hline & Sick leave & $\begin{array}{l}\text { "I have to take a lot of sick leave from physical illness resulting from burnout." } \\
\text { (P608, Assistant medical officer) }\end{array}$ \\
\hline \multirow{7}{*}{ Physical } & Headaches & $\begin{array}{l}\text { "My body is exhausted, I got frequent headaches as my mind is focusing hard } \\
\text { on the never-ending job." } \\
\text { (P862, Lab technologist) }\end{array}$ \\
\hline & Muscular pain & $\begin{array}{l}\text { "I got muscle aches at my back, shoulders and neck." } \\
\text { (P111, Medical resident) }\end{array}$ \\
\hline & Sleep disturbance & $\begin{array}{l}\text { "Every time I got home, I fall asleep easily and frequently awake at night. The } \\
\text { sleep quality is bad." } \\
\text { (P203, Assistant medical officer) } \\
\text { "In this pandemic time, it's really hard to fall asleep and wake up at the } \\
\text { morning to work. I had panic attacks at nights and was awake several times } \\
\text { because of palpitation." } \\
\text { (P587, Pharmacist) }\end{array}$ \\
\hline & Ailments & $\begin{array}{l}\text { "I had frequent episodes of upper respiratory tract infection." } \\
\text { (P781, Assistant medical officer) } \\
\text { "My blood pressure and heart rate went up many times." } \\
\text { (P174, Lab technologist) }\end{array}$ \\
\hline & Palpitations & $\begin{array}{l}\text { "I always get palpitations and difficulty sleeping at night. I am scared that I } \\
\text { might have done some mistakes, I feel worthless." } \\
\text { (P676, Medical resident) }\end{array}$ \\
\hline & Loss of appetite & $\begin{array}{l}\text { "I have lost appetite, feel down and less happy." } \\
\text { (P640, Assistant medical officer) }\end{array}$ \\
\hline & $\begin{array}{l}\text { Near-/Multi-vehicle } \\
\text { accidents }\end{array}$ & $\begin{array}{l}\text { "I got so exhausted and involved with an accident. My car crashed into three } \\
\text { other cars due to microsleep. Thank God, both of my children were unhurt." } \\
\text { (P761, Medical resident) }\end{array}$ \\
\hline \multirow[t]{2}{*}{ Psychological } & Irritability & $\begin{array}{l}\text { "I become easily angry and irritable while waiting for my own COVID-19 test } \\
\text { result. I am worried for my family if I am infected. I seem to lose my passion } \\
\text { in this career." } \\
\text { (P598, General practitioner) } \\
\text { "I came back from work with unstable emotion and everything is not right. I } \\
\text { lashed it out to my innocent children." } \\
\text { (P520, Hospital food preparation personnel) }\end{array}$ \\
\hline & Anger outbursts & $\begin{array}{l}\text { "I am easily enraged over small mistakes by the interns during ward round." } \\
\text { (P63, Specialist doctor) } \\
\text { "I had more fights with family members and co-workers." } \\
\text { (P846, Medical resident) }\end{array}$ \\
\hline
\end{tabular}


Table 8. Cont.

\begin{tabular}{|c|c|c|}
\hline Theme & Coding & Quotations \\
\hline & Anxiety symptoms & $\begin{array}{l}\text { "I get chest pain episodes since COVID-19 started. It just happened when I } \\
\text { kept thinking about work or schedules." } \\
\text { (P154, Lab technologist) } \\
\text { "Every time I get sore throat, tired or runny nose, I think it is COVID-19. The } \\
\text { anxiety is real." } \\
\text { (P210, Lab technologist) } \\
\text { "I work in fear. I came to work thinking all of worst possibilities. After work, I } \\
\text { disinfect all of my belongings just to prevent possible transmission." } \\
\text { (P424, Pharmacist) } \\
\text { "I get exhausted mostly from frequent PPE changes when attending patients. I } \\
\text { am tired mentally. I am worried that I could spread the virus that I had to } \\
\text { distract myself from those thinking. I avoid socializing with my family } \\
\text { because of this worry." } \\
\text { (P677, Medical intern) } \\
\text { "Mentally exhausted, as we need to care for other person and their } \\
\text { well-being... kids need to be sent to their grandparents... I cannot help but feel } \\
\text { very guilty to the kids." } \\
\text { (P132, Specialist doctor) }\end{array}$ \\
\hline & Feeling worthless & $\begin{array}{l}\text { "I feel useless and aimless." } \\
\text { (P588, Nurse) }\end{array}$ \\
\hline \multirow{2}{*}{ Social } & Family relationship & $\begin{array}{l}\text { "This (pandemic) made things very difficult for me and my partner." } \\
\text { (P601, Medical resident) } \\
\text { "I fell asleep as soon as I reached home. I've lost the time with my wife and } \\
\text { kids." } \\
\text { (P632, Lab technologist) }\end{array}$ \\
\hline & Quality of life & $\begin{array}{l}\text { "I've spent all my energy at work and I have barely any time to do anything } \\
\text { else I like doing." } \\
\text { (P597, Nurse) } \\
\text { "I cannot do any social activities or going back to my family during the break. I } \\
\text { just lay down and unable to wake up even to have proper meal." } \\
\text { (P800, Lab technologist) }\end{array}$ \\
\hline No impact & Coping well & $\begin{array}{l}\text { "It didn't affect me much. I am used to this." } \\
\text { (P165, Medical intern) } \\
\text { "I started to feel those burnout symptoms towards the end of the week but I } \\
\text { find them manageable." } \\
\text { (P197, Allied health member) } \\
\text { "There is no obvious sign that it impact my work quality. We are used to } \\
\text { on-call and overtime so that helps us to adapt to the pandemic." } \\
\text { (P719, Lab technologist) }\end{array}$ \\
\hline
\end{tabular}

\section{Discussions}

To the best of our knowledge, this is among the few studies that have looked at the impact of the COVID-19 pandemic on HCW from a mixed-method perspective. Our quantitative findings indicated that more than half of the Malaysian HCW in this sample experienced burnout. These findings was similar to studies done on Singapore HCW $(49.2 \%)$ and Indian HCW $(44.6 \%)[39,40]$ and were lower than the prevalence obtained from a sample of United Kingdom HCW (79\%) [41]. Through use of the Maslach Burnout Inventory, other studies revealed similar prevalences-Spanish HCW (15-82\%), Romanian residents $(76 \%)$, Italian HCW (25-53\%), Wuhan HCW (13-61\%), and Japanese HCW (31.4\%) [42-46]. While studies comparing burnout occurrences among the types of HCW and workplace settings are limited, we found that health inspectors and HCW in medical laboratories had the highest prevalences of work-related burnout. On top of their regular duties, health inspectors are heavily involved in COVID-19 contact tracking, screening, and decontamination processes [47]. HCW in medical laboratories have experienced in- 
creased workloads as Malaysia has upgraded its COVID-19 diagnostic capacity by $86 \%$ [48]. A study in Japan revealed that laboratory medical personnel were 6.1 times more likely to develop burnout when compared to physicians during COVID-19 [46].

Our findings corroborate a previous study in China, which revealed higher anxiety in HCW who were directly involved with COVID-19 [49]. In contrast, studies conducted among Wuhan and Romanian HCW showed lower burnout occurrences in HCW working on the front lines [42,44]. Consistent with other studies, HCW working more than $60 \mathrm{~h}$ per week were shown to have higher burnout scores. Longer hours are associated with prolonged contact, the prolonged wearing of PPE, and sleep deprivation, and this may emphasize burnout development [9].

In terms of personal demographics, younger HCW were at a higher risk of developing burnout, and similar findings were found in studies conducted in the United Kingdom, Spain, Turkey, and Japan $[12,41,43,46]$. This is consistent with previous research on burnout dynamics, which suggested that organizational newcomers are more prone to developing burnout when work demands outpace their resources to cope [50]. Married HCW and those with children were associated with decreased odds of developing burnout, and this is consistent with studies measuring depression, anxiety, and stress in HCW during the COVID-19 pandemic [12,51]. Families may function as social support for HCW, and strong social support was linked to a lower risk of burnout [52]. Although it was not described in previous studies, we found that inadequate childcare support during COVID-19 increased the odds of developing burnout. Long hours and unpredictable schedules can further stretch HCW during the pandemic when they cannot find childcare support [53].

Through a multivariate regression analysis, we found that having a medical condition and inadequately perceived psychological support at the workplace increased the odds of developing burnout. A medical condition might also predispose HCW more to exhaustion as compared to healthy HCW. While a study in Turkey found no association between having a medical condition and psychological distress during the pandemic [12], a study in United Kingdom HCW revealed a significant association between background illness and burnout [41]. HCW who receive adequate psychological support at work have an outlet to discuss their experiences, concerns, and emotions, and various studies have shown an association with HCW's psychological well-being during COVID-19 [4,9,12,41].

Spiritual intelligence was found to positively impact work performances among Malaysian nurses and deemed as an important quality to cope with stressful work demands [54]. While the relationship between spiritual practices and HCW burnout in a pandemic context has not yet been established, our data support previous findings where spiritual practices were found to correlate negatively with burnout [55]. Spiritual practices provide a source of comfort and hope during adversities and are increasingly recognized as an important resource in addressing burnout [56].

Our qualitative findings can be categorized into sources of burnout, burnout symptoms, coping strategies, and impacts. While sources of burnout among HCW are less described in the literature, we found that the themes (workload, uncertainty from the pandemic, a challenged work-family balance, and stretched work relationships) were partially similar and also unique when compared to the stressors experienced in general employee contexts (safety, infobesity, quarantine, stigma, and job insecurity) [57]. Compared to the general public, who were mostly in quarantine, HCW struggled with their workloads and work-family balance as they were providing patient care. HCW also faced additional strain, as they had to wear PPE and deal with the fear of transmitting the virus to their family when they returned home. As for the symptoms, in line with the long trajectory of COVID-19, our findings are in accord with previous studies that showed exhaustion as the major symptom experienced by burnt-out HCW, followed by cynicism and a reduced feeling of personal accomplishment [42,43].

Despite the challenges faced in pandemic times, many HCW experiencing burnout described problem-focused, positive thinking, and support-seeking as methods for coping compared to maladaptive coping. This parallels a study in New York, which found that 
most HCW engaged in physical activities, support groups, and spiritual practices as part of their stress-reduction activities [58]. Positive thinking or optimism was found to reduce stress and exhaustion among HCW in Turkey during COVID-19 [59]. However, similar to a study by Chor et al. (2020), some HCW resorted to maladaptive coping; coping skills intervention may play some role in addressing burnout among HCW [60]. Many HCW described physical impacts, followed by occupational, psychological, and social impacts, and this seems to be consistent with a study in Italy that reported irritability, appetite change, sleep disturbance, muscle tension, and exaggerated reactions as the major perceived impacts among its HCW [45]. These findings strongly indicate that "well-being support" for HCW during the pandemic is critical and vital to ensure their well-being-well HCW, well society!

Our study has a number of limitations. First, the sample size was relatively small compared to the actual HCW population in Malaysia. However, we found no significant prevalence differences between the first 50\% and last 50\% participants scores, which could suggest low nonresponse bias in the sample [61]. Second, the nonprobability sampling used in this study limited its generalizability to a larger context. Third, the findings came from a cross-sectional and qualitative study design and were not causal effects. Fourth, as the burnout and sociodemographic variables were captured from a self-reported instrument, so there might be a possibility of reporting bias. Despite the limitations, these findings offer an early insight on HCW burnout in Malaysian HCW and some guidance for possible interventions.

\section{Conclusions}

The study indicates that more than half of Malaysian HCW in this sample experienced burnout during the COVID-19 pandemic. HCW with direct involvement in COVID-19, a medical condition, or inadequate psychological support at work were at higher risks of developing personal-, work-, and patient-related burnout. Through a qualitative analysis, exhaustion appeared to be the most-described symptom, and many participants described problem-focused coping to deal with their ongoing stressors. However, COVID-19 has been ongoing for a year, and continuous strain may exhaust HCW's resources for coping. As the pandemic trajectory is yet unknown, ongoing well-being measures, support, and longitudinal studies on burnout intervention for HCW are desirable.

Author Contributions: Conceptualization, N.S.R. and A.R.A.; methodology, N.S.R., K.M., M.S.B.Y., and A.R.A.; data collection and formal analysis, N.S.R. and M.S.B.Y.; and writing-original draft preparation and review and editing, N.S.R., K.M., M.S.B.Y., and A.R.A. All authors have read and agreed to the published version of the manuscript.

Funding: This research received no external funding.

Institutional Review Board Statement: This study was conducted according to the guidelines of the Declaration of Helsinki and approved by the Medical Research \& Ethics Committee from the Ministry of Health Malaysia (NMRR-20-626-54485) and Universiti Sains Malaysia (COVID19-15).

Informed Consent Statement: Informed consent was obtained from all subjects involved in the study.

Data Availability Statement: The data presented in this study are available on request from the corresponding author.

Acknowledgments: We would like to thank the Director General of Health Malaysia for the permission to publish these findings.

Conflicts of Interest: The authors declare no conflict of interest.

\section{References}

1. Wu, J.T.; Leung, K.; Bushman, M.; Kishore, N.; Niehus, R.; de Salazar, P.M.; Cowling, B.J.; Lipsitch, M.; Leung, G.M. Estimating clinical severity of COVID-19 from the transmission dynamics in Wuhan, China. Nat. Med. 2020, 26, 506-510. [CrossRef] [PubMed] 
2. Huang, L.; Zhang, X.; Zhang, X.; Wei, Z.; Zhang, L.; Xu, J.; Liang, P.; Xu, Y.; Zhang, C.; Xu, A. Rapid asymptomatic transmission of COVID-19 during the incubation period demonstrating strong infectivity in a cluster of youngsters aged 16-23 years outside Wuhan and characteristics of young patients with COVID-19: A prospective contact-tracing study. J. Infect. 2020, 80, e1-e13. [CrossRef] [PubMed]

3. World Health Organization. WHO Announces COVID-19 Outbreak a Pandemic [Internet]. 2020. Available online: https: / /www.euro.who.int/en/health-topics/health-emergencies/coronavirus-covid-19/news/news/2020/3/who-announcescovid-19-outbreak-a-pandemic (accessed on 10 November 2020).

4. Conversano, C.; Marchi, L.; Miniati, M. Psychological distress among healthcare professionals involved in the COVID-19 emergency: Vulnerability and resilience factors. Clin. Neuropsychiatry 2020, 17, 94-96.

5. Nguyen, L.H.; Drew, D.A.; Joshi, A.D.; Guo, C.-G.; Ma, W.; Mehta, R.S.; Sikavi, D.R.; Lo, C.-H.; Kwon, S.; Song, M.; et al. Risk of COVID-19 among frontline healthcare workers and the general community: A prospective cohort study. medRxiv Prepr. Serv. Heal. Sci. 2020. [CrossRef]

6. Shanmugam, H.; Juhari, J.A.; Nair, P.; Chow, S.K.; Ng, C.G. Impacts of COVID-19 Pandemic on Mental Health in Malaysia: A Single Thread of Hope. Malays. J. Psychiatry 2020, 29, 1.

7. Tam, C.W.C.; Pang, E.P.F.; Lam, L.C.W.; Chiu, H.F.K. Severe acute respiratory syndrome (SARS) in Hongkong in 2003: Stress and psychological impact among frontline healthcare workers. Psychol. Med. 2004, 34, 1197-1204. [CrossRef]

8. Pan, R.; Zhang, L.; Pan, J. The anxiety status of Chinese medical workers during the epidemic of COVID-19: A meta-analysis. Psychiatry Investig. 2020, 17, 475-480. [CrossRef]

9. Mo, Y.; Deng, L.; Zhang, L.; Lang, Q.; Liao, C.; Wang, N.; Qin, M.; Huang, H. Work stress among Chinese nurses to support Wuhan in fighting against COVID-19 epidemic. J. Nurs. Manag. 2020, 28, 1002-1009. [CrossRef]

10. Chen, Y.; Zhou, H.; Zhou, Y.; Zhou, F. Prevalence of self-reported depression and anxiety among pediatric medical staff members during the COVID-19 outbreak in Guiyang, China. Psychiatry Res. 2020, 288, 113005. [CrossRef]

11. Apisarnthanarak, A.; Apisarnthanarak, P.; Siripraparat, C.; Saengaram, P.; Leeprechanon, N.; Weber, D.J. Impact of Anxiety and Fear for COVID-19 Toward Infection Control Practices among Thai Healthcare Workers. Infect. Control Hosp. Epidemiol. 2020, 1-2. [CrossRef]

12. Elbay, R.Y.; Kurtulmuş, A.; Arpacıŏlu, S.; Karadere, E. Depression, anxiety, stress levels of physicians and associated factors in Covid-19 pandemics. Psychiatry Res. 2020, 290, 1-5. [CrossRef] [PubMed]

13. World Health Organization. International Statistical Classification of Diseases and Related Health Problems, 11th ed.; World Health Organization: Geneva, Switzerland, 2020.

14. Koutsimani, P.; Montgomery, A.; Georganta, K. The relationship between burnout, depression, and anxiety: A systematic review and meta-analysis. Front. Psychol. 2019, 10, 1-19. [CrossRef] [PubMed]

15. Maslach, C.; Schaufeli, W.B.; Leiter, M.P. Job Burnout. Annu. Rev. Psychol. 2001, 52, 397-422. [CrossRef]

16. Iacovides, A.; Fountoulakis, K.N.; Kaprinis, S.; Kaprinis, G. The relationship between job stress, burnout and clinical depression. J. Affect. Disord. 2003, 75, 209-221. [CrossRef]

17. Shakirah, M.; Ang, Z.; Jailani, A.; Cheah, K.; Kong, Y.; Selvarajah, S.; Balqis-Ali, N.; Fun, W.; Sararaks, S. The COVID-19 Chronicles of Malaysia; National Institutes of Health: Setia Alam, Selangor, 2020.

18. Dyrbye, L.; West, C.P.; Satele, D.; Boone, S.; Tan, L.; Sloan, J.; Shanafelt, T.D. Burnout Among U.S. Medical Students, Residents, and Early Career Physicians Relative to the General U.S. Population. Acad. Med. 2014, 89, 443-451. [CrossRef]

19. McCain, R.S.; McKinley, N.; Dempster, M.; Campbell, W.J.; Kirk, S.J. A study of the relationship between resilience, burnout and coping strategies in doctors. Postgrad. Med. J. 2018, 94, 43-47. [CrossRef]

20. Mattei, A.; Fiasca, F.; Mazzei, M.; Abbossida, V.; Bianchini, V. Burnout among healthcare workers at L'Aquila: Its prevalence and associated factors. Psychol. Health Med. 2017, 22, 1262-1270. [CrossRef]

21. Fujitani, K.; Carroll, M.; Yanagisawa, R.; Katz, C. Burnout and Psychiatric Distress in Local Caregivers Two Years After the 2011 Great East Japan Earthquake and Fukushima Nuclear Radiation Disaster. Community Ment. Health J. 2016, 52, 39-45. [CrossRef]

22. West, C.P.; Dyrbye, L.N.; Shanafelt, T.D. Physician burnout: Contributors, consequences and solutions. J. Intern. Med. 2018, 283, 516-529. [CrossRef]

23. Maslach, C.; Leiter, M.P. Understanding the burnout experience: Recent research and its implications for psychiatry. World Psychiatry 2016, 15, 103-111. [CrossRef]

24. Shanafelt, T.D.; Boone, S.; Tan, L.; Dyrbye, L.N.; Sotile, W.; Satele, D.; West, C.P.; Sloan, J.; Oreskovich, M.R. Burnout and satisfaction with work-life balance among US physicians relative to the general US population. Arch. Intern. Med. 2012, 172, 1377-1385. [CrossRef] [PubMed]

25. Dyrbye, L.; Shanafelt, T.D.; Balch, C.M.; Satele, D.; Sloan, J.; Freischlag, J. Relationship between work-home conflicts and burnout among American surgeons: A comparison by sex. Arch. Surg. 2011, 146, 211-217. [CrossRef] [PubMed]

26. Kaur, D.; Sambasivan, M.; Kumar, N. Effect of spiritual intelligence, emotional intelligence, psychological ownership and burnout on caring behaviour of nurses: A cross-sectional study. J. Clin. Nurs. 2013, 22, 3192-3202. [CrossRef] [PubMed]

27. Bakker, A.B.; Demerouti, E. The Job Demands-Resources model: State of the art. J. Manag. Psychol. 2007, 22, 309-328. [CrossRef]

28. Gorter, R.C.; Eijkman, M.A.J.; Hoogstraten, J. Burnout and health among Dutch dentists. Eur. J. Oral Sci. 2000, 108, $261-267$. [CrossRef] [PubMed] 
29. Patel, R.S.; Bachu, R.; Adikey, A.; Malik, M.; Shah, M. Factors related to physician burnout and its consequences: A review. Behav. Sci. 2018, 8, 1-7. [CrossRef]

30. Ripp, J.; Babyatsky, M.; Fallar, R.; Bazari, H.; Bellini, L.; Kapadia, C.; Katz, J.T.; Pecker, M.; Korenstein, D. The incidence and predictors of job burnout in first-year internal medicine residents: A five-institution study. Acad. Med. 2011, 86, 1304-1310. [CrossRef]

31. Creswell, J.; Pioano Clark, V. Choosing a mixed method design. In Designing and Conducting Mixed Methods Research; SAGE Publications Ltd.: Thousand Oaks, CA, USA, 2007; pp. 58-89.

32. Reiners, G.M. Understanding the Differences between Husserl's (Descriptive) and Heidegger's (Interpretive) Phenomenological Research. J. Nurs. Care 2012, 1, 1-3. [CrossRef]

33. Soper, D. A-priori Sample Size Calculator for Multiple Regression [Software] [Internet]. 2015. Available online: http://www. danielsoper.com/statcalc (accessed on 15 March 2020).

34. Kristensen, T.S.; Borritz, M.; Villadsen, E.; Christensen, K.B. The Copenhagen Burnout Inventory: A new tool for the assessment of burnout. Work Stress 2005, 19, 192-207. [CrossRef]

35. Talaee, N.; Varahram, M.; Jamaati, H.; Salimi, A.; Attarchi, M.; Kazempour dizaji, M.; Sadr, M.; Hassani, S.; Farzanegan, B.; Monjazebi, F.; et al. Stress and burnout in health care workers during COVID-19 pandemic: Validation of a questionnaire. J. Public Health 2020. [CrossRef]

36. Andrew Chin, R.W.; Chua, Y.Y.; Chu, M.N.; Mahadi, N.F.; Wong, M.S.; Yusoff, M.S.B.; Lee, Y.Y. Investigating validity evidence of the Malay translation of the Copenhagen Burnout Inventory. J. Taibah Univ. Med. Sci. 2018, 13, 1-9. [CrossRef] [PubMed]

37. Thrush, C.R.; Guise, J.B.; Gathright, M.M.; Messias, E.; Flynn, V.; Belknap, T.; Thapa, P.B.; Williams, D.K.; Nada, E.M.; Clardy, J.A. A One-Year Institutional View of Resident Physician Burnout. Acad. Psychiatry 2019, 43, 361-368. [CrossRef] [PubMed]

38. Guba, E.G. Criteria for Assessing the Trustworthiness of Naturalistic Inquiries. Educ. Commun. Technol. J. 1981, $29,75-91$.

39. Khasne, R.; Dhakulkar, B.; Mahajan, H.; Kulkarni, A. Burnout among Healthcare Workers during COVID-19 Pandemic in India: Results of a Questionnaire-based Survey. Indian J. Crit. Care Med. 2020, 24, 664-671. [CrossRef] [PubMed]

40. Chor, W.P.D.; Ng, W.M.; Cheng, L.; Situ, W.; Chong, J.W.; Ng, L.Y.A.; Mok, P.L.; Yau, Y.W.; Lin, Z. Burnout amongst emergency healthcare workers during the COVID-19 pandemic: A multi-center study. Am. J. Emerg. Med. 2020, 3-5. [CrossRef]

41. Ferry, A.V.; Wereski, R.; Strachan, F.E.; Mills, N.L.; Ferry, A. Predictors of healthcare worker burnout during the COVID-19 pandemic. medRxiv 2020. [CrossRef]

42. Dimitriu, M.C.T.; Pantea-Stoian, A.; Smaranda, A.C.; Nica, A.A.; Carap, A.C.; Constantin, V.D.; Davitoiu, A.M.; Cirstoveanu, C.; Bacalbasa, N.; Bratu, O.G.; et al. Burnout syndrome in Romanian medical residents in time of the COVID-19 pandemic. Med. Hypotheses 2020, 144, 109972. [CrossRef]

43. Luceño-Moreno, L.; Talavera-Velasco, B.; García-Albuerne, Y.; Martín-García, J. Symptoms of Posttraumatic Stress, Anxiety, Depression, Levels of Resilience and Burnout in Spanish Health Personnel during the COVID-19 Pandemic. Int. J. Environ. Res. Public Health 2020, 17, 5514. [CrossRef]

44. Wu, Y.; Wang, J.; Luo, C.; Hu, S.; Lin, X.; Anderson, A.E.; Bruera, E.; Yang, X.; Wei, S.; Qian, Y. A Comparison of Burnout Frequency Among Oncology Physicians and Nurses Working on the Frontline and Usual Wards During the COVID-19 Epidemic in Wuhan, China. J. Pain Symptom Manag. 2020, 60, e60-e65. [CrossRef]

45. Barello, S.; Palamenghi, L.; Graffigna, G. Burnout and somatic symptoms among frontline healthcare professionals at the peak of the Italian COVID-19 pandemic. Psychiatry Res. 2020, 290, 113129. [CrossRef]

46. Matsuo, T.; Kobayashi, D.; Taki, F.; Sakamoto, F.; Uehara, Y.; Mori, N.; Fukui, T. Prevalence of Health Care Worker Burnout During the Coronavirus Disease 2019 (COVID-19) Pandemic in Japan. JAMA Netw. Open 2020, 3, 1-4. [CrossRef] [PubMed]

47. Jalaludin, J.; Sumbangan Pengamal Kesihatan Persekitaran Wajar Dihargai [Internet]. Malaysia Gazette. 2020 [cited 2020 Aug 16]. Available online: https:/ / malaysiagazette.com/2020/04/19/sumbangan-pengamal-kesihatan-persekitaran-wajar-dihargai/ (accessed on 8 August 2020).

48. Rahman, F. The Malaysian Response to COVID-19: Building Preparedness for 'Surge Capacity', Testing Efficiency, and Containment; Desk of the Director-General of Health Malaysia: Putrajaya, Malaysia, 2020.

49. Liu, C.Y.; Yang, Y.Z.; Zhang, X.M.; Xu, X.; Dou, Q.L.; Zhang, W.W.; Cheng, A.S.K. The prevalence and influencing factors in anxiety in medical workers fighting COVID-19 in China: A cross-sectional survey. Epidemiol. Infect. 2020, 148, 1-7. [CrossRef] [PubMed]

50. Dunford, B.B.; Shipp, A.J.; Wayne Boss, R.; Angermeier, I.; Boss, A.D. Is burnout static or dynamic? A career transition perspective of employee burnout trajectories. J. Appl. Psychol. 2012, 97, 637-650. [CrossRef] [PubMed]

51. Shacham, M.; Hamama-Raz, Y.; Kolerman, R.; Mijiritsky, O.; Ben-Ezra, M.; Mijiritsky, E. COVID-19 factors and psychological factors associated with elevated psychological distress among dentists and dental hygienists in Israel. Int. J. Environ. Res. Public Health 2020, 17, 2900. [CrossRef]

52. Sun, H.; Warner, D.O.; Macario, A.; Zhou, Y.; Culley, D.J.; Keegan, M.T. Repeated Cross-sectional Surveys of Burnout, Distress, and Depression among Anesthesiology Residents and First-year Graduates. Anesthesiology 2019, 131, 668-677. [CrossRef]

53. Kannampallil, T.G.; Goss, C.W.; Evanoff, B.A.; Strickland, J.R.; McAlister, R.P.; Duncan, J. Exposure to COVID-19 patients increases physician trainee stress and burnout. PLOS ONE 2020, 15, e0237301. [CrossRef]

54. Rani, A.A.; Abidin, I.; Rashid, A.H.; Rashid, M.; Hamid, A. The Impact of Spiritual Intelligence on Work Performance: Case studies in Government Hospitals of East Coast of Malaysia. Macrotheme Rev. 2013, 2, 46-59. 
55. Doolittle, B.R.; Windish, D.M.; Seelig, C.B. Burnout, Coping, and Spirituality Among Internal Medicine Resident Physicians. J. Grad. Med. Educ. 2013, 5, 257-261. [CrossRef]

56. Malik, S.; Riaz, N.; Nazir, S. Personal Spirituality and Work Attitudes Among Doctors. J. Behav. Sci. 2015, 25, 136-149.

57. Hamouche, S. COVID-19 and employees' mental health: Stressors, moderators and agenda for organizational actions. Emerald Open Res. 2020, 2, 15. [CrossRef]

58. Shechter, A.; Diaz, F.; Moise, N.; Anstey, D.E.; Ye, S.; Agarwal, S.; Birk, J.L.; Brodie, D.; Cannone, D.E.; Chang, B.; et al. Psychological distress, coping behaviors, and preferences for support among New York healthcare workers during the COVID-19 pandemic. Gen. Hosp. Psychiatry 2020, 66, 1-8. [CrossRef] [PubMed]

59. Özdemir, Ş.; Kerse, G. The Effects of COVID 19 on Health Care Workers: Analysing of the Interaction between Optimism, Job Stress and Emotional Exhaustion. Int. Multidiscip. J. Soc. Sci. 2020, 9, 178-201. [CrossRef]

60. Penberthy, J.K.; Chhabra, D.; Ducar, D.M.; Avitabile, N.; Lynch, M.; Khanna, S.; Xu, Y.; Ait-Daoud, N.; Schorling, J. Impact of Coping and Communication Skills Program on Physician Burnout, Quality of Life, and Emotional Flooding. Saf. Health Work 2018, 9, 381-387. [CrossRef] [PubMed]

61. Johnson, T.P.; Wislar, J.S. Response rates and nonresponse errors in surveys. JAMA J. Am. Med. Assoc. 2012, 307, 1805-1806. [CrossRef] [PubMed] 